\title{
O ano em que Álvaro \\ de Campos foi \\ publicado no Brasil
}

\author{
Luís Camargo
}


Na biografia fictícia inventada por Fernando Pessoa, Ricardo Reis teria se exilado no Brasil a partir de 1919. Na vida real, dez anos mais tarde, foram publicados no Brasil alguns fragmentos da "Ode Triunfal", de Álvaro de Campos, em uma tese apresentada ao concurso da cadeira de literatura da Escola Normal do Distrito Federal, O espírito vitorioso, de Cecília Meireles ${ }^{1}$ Entretanto, Cecília M eireles não indica nem o título nem o autor dos fragmentos.

Segundo E dson Nery da Fonseca, os primeiros textos críticos sobre Fernando Pessoa no Brasil são as referências de Cecília Meireles em seu prefácio a Poetas novos de Portugal ${ }^{1}$, cuja primeira edição foi impressa em março de 1944; o artigo "Fernando Pessoa", de Murilo Mendes, publicado na Folha da Manhã, de Recife, em 10 de dezembro de 1944; e um ensaio de Lúcio Cardoso publicado no suplemento Letras e Artes, do jornal A Manhã, do Rio de J aneiro, em 21 de julho de 1946. Esses textos foram reproduzidos por Edson Nery da Fonseca em seu livro Três poetas brasi lei ros apaixonados por Fernando Pessoa. Assim, os fragmentos a seguir, reproduzidos com os comentários de Cecília M eireles que os apresentam e os seguem, são - provavelmente - os primeiros de Álvaro de Campos - e do próprio Fernando Pessoa - publicados no Brasil (M eireles, 1924, p. 119-120).

Os poetas de hoje, com uma voz igual a de todos os homens do passado conseguiram cantar as cantigas que eles tinham apenas desejado ouvir. Deixaram a rima como um ador-

1. Cecília Meireles, O espírito vitorioso: tese apresentada ao concurso da cadeira de literatura da Escola Normal do Distrito Federal em 1929. Rio de J aneiro: Anuário do Brasil, 1929. O acesso a este livro foi possível graças à generosidade do bibliófilo Waldemar Torres. 
no desnecessário: porque vão falar de coisas tão amplas que as almas se maravilharão só com as medidas infinitas reveladas nessa voz.

Tudo poderá ser cantado, porque tudo encerra em si um sentido de poesia profunda: a secreta essência que anima a vida.

O poeta será o unificador dos destinos, o construtor da solidariedade universal. Que importa como se chame? Não é o próprio espírito humano que se está fazendo sensível, para se comunicar e se propagar com elevado amor?

Fraternidade com todas as dinâmicas!

Promíscua fúria de ser parte agente

Do rodar férreo e cosmopolita

Dos comboios estrénuos,

Da faina transportadora-de-cargas dos navios,

Do giro lúbrico e lento dos guindastes,

Do tumulto disciplinado das fábricas,

E do quase silêncio ciciante e monótono das correias de transmissão!

Amo-vos a todos, a tudo, como uma fera,

Amo-vos carnivoramente,

Pervertidamente e enroscando a minha vista

Em vós, ó coisas grandes, banais, úteis, inúteis,

Ó coisas todas modernas,

Ó minhas contemporâneas, forma atual e próxima

Do sistema imediato do Universo!

Nova R evelação metálica e dinâmica de Deus!

Eia, electricidade, nervos doentes da M atéria!

Eia, telegrafia-sem-fios, simpatia metálica do inconsciente!

Eia, todo o passado dentro do presente!

Eia, todo o futuro já dentro de nós! eia!

A h! não ser eu toda a gente e toda a parte!

Nessa confraternização vai toda a experiência vivida pelas almas ultra-sensíveis, que se destacaram da turba pela sua faculdade especial de registrar cada inquietação e cada surto evolutivo da humanidade. (M eireles, 1929, p. 119-120)

2. Na edição das Poesias de Álvaro de Campos (Lisboa, Ática, 1951) consta hífen entre parte e agente no segundo verso (parte-agente); não consta vírgula após os diversos Eia; inconsci ente está grafado com inicial maiúscula e não consta ponto de exclamação após o Ah do último verso (p. 143 e p. 152). 


\section{R eferências bibliográficas}

CAMPOS, Alvaro de. Poesias. Lisboa: Ática, 1951

MEIRELLES, Cecília. O espírito Vitorioso. R io de J aneiro: Anuário do Brasil, 1929. (Tese apresentada ao concurso da cadeira de literatura da Escola Normal do Distrito Federal.) . Poetas novos de Portugal. Rio de J aneiro: Dois Mundos, 1944. (Clássicos e Contemporâneos.)

; MENDES, Murilo \& CARDOSO, Lúcio. Três poetas brasileiros apaixonados por Fernando Pessoa. Organização e apresentação Edson Nery da Fonseca. Recife: Fundação J oaquim Nabuco: Massangana, 1985. 